\title{
Recollections 1
}

\section{BERTHA JEFFREYS}

Early years

I have recently had occasion to look at my copy of A School Geometry by H. S. Hall and F. H. Stevens; it is the second edition of 1904 and the preface to the first edition is dated 1903, the year when I was born. It is a complimentary copy sent to my mother, Harriett Swirles, in 1905 when, on the death of my father, she started a small private school in Northampton. The preface begins, 'The present book provides a course of Elementary Geometry based on the recommendations of the Mathematical Association and on the schedule recently proposed and adopted at Cambridge.' The book was well used and there are notes in my aunt's handwriting of the requirements for the Cambridge Local Examinations and in mine for Oxford Senior in 1917.

I have felt slightly ashamed that I cannot give the exact reference to Euclid for a particular theorem as my husband used to do. His copy of Euclid Revised (1899, Oxford) by R. C. Nixon is inscribed 'Harold Jeffreys, 1st Year, Armstrong College, Newcastle'.

Preparing for war

At a sub-committee of the Teaching Committee in London in the summer of 1939 when war was imminent, there was discussion of evacuation of schools. A. C. Heath of St Paul's School said that they planned to do it on bicycles. He was the Scoutmaster and the master in charge of the OTC was also a mathematician so it would be all right. I think we all nodded agreement, but I did not hear if it came off successfully.

I have learned from the archivist of St Paul's School that their wartime home was Easthampstead Park near Crowthorne and A. C. Heath's daughter, Mrs Jane Clarke, remembers that the main evacuation was carried out by lorry, car, etc. However, the boys lived in billets or hostels in Crowthorne and the only transport to the 'Mansion' was by bicycle; all the boys had to cycle the three miles, sometimes four times a day.

Joint Report with the Institute of Physics

The Joint Report of the Mathematical Association and the Institute of Physics on The Teaching of Mathematics to Physicists was published in 1944. I have a copy of it and of the agenda and minutes of the meetings, together with part of the correspondence, some typed, some handwritten. Today this would be replaced by e-mail and fax. Reference is made to the report in [1, pp. 164, 297].

The Chairman of the joint committee was Professor J. A. Crowther of the University of Reading where the Institute of Physics had its war-time home; the IoP Secretary, Dr H. R. Lang, was Secretary of the committee. Its constitution varied slightly from time to time and the numbers were about evenly divided, roughly six a side. University departments, a Technical College, the Schools Inspectorate and industry were represented and the 
Mathematical Association had one schoolmaster, A. A. Robson of Marlborough College.

We met three times in 1943. The January meeting was something of a free-for-all and on 2 February Professor W. G. Bickley wrote to me "Are you beginning to recover from the welter of Saturday afternoon?'. For the May and October meetings drafts and comments were submitted for a Report and an Appendix containing Schedules of topics to be studied at different stages. A version was discussed at a meeting in January 1944 and after a further opportunity for written comments it was left to the Chairman to send it to press.

The Secretary submitted a memorandum to the Board of the Institute of Physics on 23 October 1944. 5000 copies were distributed and The Times Educational Supplement commented that it "can be strongly commended to the attention of those concerned with the teaching of mathematics at all levels ... a notable and timely contribution'. The report contained an anecdote from Sir J. J. Thomson's Recollections and Reflections about one of his pupils who in his third year had a very bad record and was persuaded to work when he saw that certain shots at billiards followed from mathematics. This appeared in the lay press as 'Mathematics made easy by billiards'.

We remarked that 'A student whose mathematical ceiling is unduly low would probably be well advised to transfer his interest from physics to some other branch of science'. Nowadays it might be difficult to find a branch in which mathematics is not needed.

In the Schedules there are sections on Numerical Methods, containing the heading, 'The principles of automatic integration and the use of such equipment as may become available to Universities after the war'. The differential analyser had been installed at Manchester in 1935 and Hartree and his team were using it for military problems, but we were far from envisaging the present computer world. Today's students grow up with quite different equipment for numerical work and this part of the Report is out of date. Most of the other topics we included need to be taught at some time in a physicist's course. How it should be done remains a matter for debate. The Institute of Physics has set up later working parties.

We were fortunate that London was peaceful at the times of our meetings. Some of the travelling must have been done by train in the blackout but I do not remember any difficulties. The first flying-bomb arrived in June 1944.

I propose to deposit my file with the archives of the Mathematical Association so that it will be available to anyone interested.

\section{Reference}

1. Michael H. Price, Mathematics for the Multitude, Mathematical Association, 1994.

BERTHA JEFFREYS, President 1969-70

160 Huntingdon Road, Cambridge CB3 OLB 